\title{
Enzyme secretion by ECM fungi and exploitation of mineral nutrients from soil organic matter
}

\author{
Karin Pritsch • Jean Garbaye
}

Received: 8 February 2010 / Accepted: 4 June 2010 /Published online: 21 January 2011

(C) The Author(s) 2011. This article is published with open access at Springerlink.com

\begin{abstract}
- Introduction Important nutrients in forest soils such as nitrogen and phosphorus are mostly recycled from natural polymeric compounds contained in litter and organic debrisfor example nucleic acids, proteins, or chitin.

- Objectives Activities of enzymes such as phosphatases, proteases, cellulases, chitinases and laccase were shown in saprotrophic but also in ectomycorrhizal fungi and there is increasing evidence that these enzymes contribute not only to the functioning of the symbiosis but also to the mobilisation of nutrients. In the present review, we describe how enzyme secretion and localisation on fungal hyphae may be connected to the potential role in soil nutrient cycling.

- Results Recently developed methods for enzyme activity studies of ectomycorrhizae directly assayed in or collected from the field such as enzyme activity profiling and soil imprinting are described. Their value and limitations in different examples of ecological studies is highlighted and discussed also with respect to the role of other soil microorganisms associated with ectomycorrhizae.
\end{abstract}

Associate Editor: Jean Garbaye

K. Pritsch $(\bowtie)$

Institute of Soil Ecology, Helmholtz Zentrum München,

German Research Center for Environmental Health,

Ingolstaedter Landstrasse 1,

85764 Neuherberg, Germany

e-mail: pritsch@helmholtz-muenchen.de

J. Garbaye

INRA, UMR 1136 Interactions Arbres Micro-organismes,

Centre INRA de Nancy,

54280 Champenoux, France
- Conclusion The conclusion from our review is that enzyme activities of ECM and their associated microorganisms provide a potentially enormous plasticity of mycorrhizosphere functionality which is an open field for further research. Enzymes secrétés par les champignons ectomycorhiziens et exploitation des éléments minéraux contenus dans la matière organique du sol.

Keywords Extracellular enzymes · Ectomycorrhiza . Nutrient mobilisation

\section{Introduction}

\section{Ectomycorrhizal fungi and nutrient exploitation}

The roots of the dominant and economically most important forest trees in temperate and boreal forests form ectomycorrhizal (ECM) symbioses with higher fungi. Over 100 different ECM species can occur in a single forest stand. This high diversity of fungal symbionts adds multiple functions to the plant host root. While many studies have been performed addressing biodiversity in forest ecosystems, only little is known on the expression of functional traits of ectomycorrhizae in the field.

Colonising the absorbing fine roots of their host plants, ECMs are involved in nutrient acquisition of their host (Smith and Read 2008). The fundamental structures of the functional symbiosis are the colonised root tips which are formed of the zone of interaction (Hartig net), the hyphal mantle, and the external myce- 
lium (Kjøller 2006). The structure of the hyphal mantle and external mycelia are mainly determined by the respective fungal symbionts. A considerable variety of mantle anatomies, surface properties, and types of extramatrical mycelia have been described with respect to their representation in different taxonomic groups (Agerer 2007). Focusing on the potential to exploit nutrients in forest litter and soil, Agerer (2001) has proposed five different exploration types according to the structure of extraradical mycelia of ECMs. Contact types have a smooth mantle with almost no extramatrical mycelium and are closely attached to the substrate. Short distance types usually have many short extramatrical hyphae and explore the soil in a distance below $1 \mathrm{~mm}$ from the root surface. Medium distance types are separated into smooth and fringe types forming rhizomorphs or hyphal bundles that mostly reach less than $1 \mathrm{~cm}$ into the soil, while long distance types have differentiated rhizomorphs with the potential to grow several $\mathrm{dm}$ into the soil. Additionally, surface properties such as hydrophobicity and hydrophily determine the interaction of ECMs with their environment. These different structural adaptations may enable mycorrhizal communities to explore different niches and optimally use nutrients therein (Bruns 1995).

Except for nitrogen which can be fixed biologically by prokaryotes, nutrient availability in soils primarily depends upon soil chemical properties and microbial nutrient cycles. Soil microorganisms including mycorrhizal fungi use several mechanisms for nutrient exploitation. Nutrient mobilisation from minerals using organic acids and siderophores has been reviewed by Rosling (2009). We will focus here on nutrient mobilisation from organic substances and especially on secreted enzymes of ectomycorrhizal fungi possibly involved in nutrient exploitation from forest litter and soil organic matter.

Enzymes catalyse biochemical reactions and therefore are involved in all biological processes including biogeochemical nutrient cycles. Several enzymes and enzyme activities similar to those of typical decomposers have been demonstrated in ectomycorrhizae and the results from mainly pure culture experiments and laboratory studies are reviewed by Leake and Read (1997). The saprotrophic potential of ECMs may reflect the fact that the ectomycorrhizal symbiosis has evolved several times independently from presumably saprotrophic groups within basidio- and ascomycetes (Bruns and Shefferson 2004; Hibbett and Matheny 2009). ECM evolution has even been related to nutrient-poor conditions with nutrients patchily distributed and often protected from mineralization by surrounding organic material (Lambers et al. 2009; Read and Perez-Moreno 2003).

\section{Forms of nutrients and natural substrates for utilisation by ECM fungi}

Radio tracer studies using ${ }^{14} \mathrm{C}$-labelled litter demonstrated that ECM root tips in the field predominantly receive carbon from plant photosynthesis rather than from litter (Treseder et al. 2006). Under conditions of reduced photosynthesis after defoliation, Cullings et al. (2008) studied enzyme activities on ECM tips of Suillus granulatus and found an increase in enzymes typical for wood rotting fungi. Saprotrophic and mycorrhizal fungi appear to use different sources within the different soil layers with ECM fungi preferentially taking up nitrogen and saprotrophic fungi favouring carbon (Hobbie and Horton 2007). However, stable isotope signatures of fruit bodies of some ECM revealed a signature intermediate between what would be expected if carbon only was provided by plant photosynthesis or from soil carbon sources, respectively (Taylor et al. 2003). This suggests differences in carbon use between ECM species. Although there is some debate on the saprotrophic capacities of ectomycorrhizae (Baldrian 2009) it is reasonable to assume that there is a biotrophic-saprotrophic continuum in ECM fungi as summarised and discussed by Koide et al. (2008) and Cullings and Courty (2009). Especially those ECM types with extensive mycelia are candidates to search for saprotrophic capacities and uptake of carbon from litter in parts of their mycelia remote from the carbon supply of their plant host.

Litter predominantly contains dead plant material, but also debris of animal, fungal, and prokaryote origin altogether affecting litter composition and degradability. Litter degradation itself is a complex process involving different trophic groups of organisms (Ponge 2003; Ponge 1991). The decaying litter material is gradually transformed and incorporated either into biomass or into different soil organic matter pools (Kalbitz et al. 2000). Each of these pools is again subject to further degradation and uptake into biomass or to sequestration into stable carbon pools. Altogether, a complex spatial and temporal dynamic in nutrient quality and quantity results from biological cycles.

\section{Enzymes of ECMs possibly involved in utilising organic bound nutrients}

In natural forest soils, the major nutrients phosphorus and nitrogen are present as organic macromolecules that need to be broken down into forms that can be taken up by plants and fungi. In addition, enzymes involved in the degradation of plant cell wall components are important to get access to nutrients enclosed 
in dead plant tissues (Leake et al. 2002; Perez-Moreno and Read 2000). To attack plant cell walls, a number of enzymes are needed: cellulases, hemicellulases, pectinases, and possibly lignin degrading enzymes. Organic nitrogen and phosphorus sources are mostly macromolecules such as proteins, chitin, and phytate or they are only accessible after degradation of surrounding materials and matrices as they are bound to or embedded in plant and fungal cell walls or humic acids (Leake et al. 2002; Read and Perez-Moreno 2003).

Organic phosphorus compounds account for $30-65 \%$ of total phosphorus in soils. Some phosphorus compounds that enter the soil such as nucleic acids and phospholipids are rapidly mineralised whereas others such as phytate are more recalcitrant thus accumulating in soils (cf. Lim et al. 2007).

Acid phosphatases or phosphomonoesterases are a group of extracellular enzymes involved in releasing phosphate groups from organic phosphates and are very widely distributed in ECM (Alexander and Hardy 1981; Alvarez et al. 2006; Antibus et al. 1992; Bae and Barton 1989; Bartlett and Lewis 1973; Conn and Dighton 2000; Courty et al. 2006; Ho 1989; Ho and Zak 1979; Hrynkiewicz et al. 2009; McElhinney and Mitchell 1993; Pasqualini et al. 1992; Tibbett et al. 1998). Phytase activity has also been found in ECM fungi, indicating their potential to access this more recalcitrant organic phosphorus resource (Antibus et al. 1992). The diversity of phosphorus mobilisation and uptake in ectomycorrhizal fungi is addressed in detail by Plassard et al. (2011) in this issue.

Sources of organic nitrogen in soils are proteins and especially in forest soils also chitin. Proteins can be used by many although not all ECM fungi as sole nitrogen source (Abuzinadah et al. 1986; Abuzinadah and Read 1986; Finlay et al. 1992; Guidot et al. 2005; Hutchison 1990; Keller 1996; Lilleskov et al. 2002; Lundeberg 1970; Rangel-Castro et al. 2002). Proteins often form protein-phenol complexes with tannins and thus become less easily degradable for microorganisms. Enzymes with the potential to break phenol-protein complexes (Bending and Read 1996; Joanisse et al. 2009; Wu et al. 2003) are largely the same as those involved in lignin degradation, namely phenoloxidases and peroxidases. While laccase genes were demonstrated in several ECM (Chen et al. 2003; Luis et al. 2005), there is only limited evidence for the presence in ECM of other lignolytic enzymes, e.g. lignin peroxidase or manganese peroxidase (Baldrian 2006; Cairney et al. 2003).

Chitin is entering soils as fungal cell walls and arthropod exoskeletons. The potential to use chitin as a nitrogen source for ECM fungi is widespread (Leake and Read 1990; Lindahl and Taylor 2004).
Within the group of secreted enzymes, those localised in the Hartig net are involved in symbiotic interactions and in regulating compatibility, modelling cell walls, and enabling the exchange of nutrient and energy flow between partners, such as invertases, ATPases, chitinases, and cellulases (Smith and Read 2008). These enzymes have been intensively studied to understand the processes leading to a functional symbiotic relationship (Martin et al. 1995; Martin et al. 1999) and are not further considered here.

\section{Possible mechanisms used by ECM fungi to secrete extracellular enzymes}

At the subcellular level, enzymes that are effective outside the fungal cell (extracellular enzymes) have to pass the fungal cell wall after synthesis. Enzymes secreted by fungi can be released in the surrounding environment where they act and break down macromolecules. However, this strategy is often observed under nutrient-rich conditions and effectively used for biotechnological production of enzymes but may be a waste of resources under conditions of nutrient competition with other fungi, microbes, plants and animals. Once released in the surrounding, enzymes may be degraded or the products of the enzyme reaction may be taken up by other soil living organisms. Thus, uncontrolled release is an uneconomic way to spend a costly resource, and indeed, several strategies have been developed by soil microbes and fungi to keep enzymes close to the producing cell. Enzymes can be embedded in extracellular polysaccharide matrices or bound to the cell wall as realised by many soil bacteria and fungi. Microscopical enzyme activity stains showed for example that phosphatase activity is localised at the cell surface of ECM fungi (Alvarez et al. 2006; Nygren and Rosling 2009; van Aarle et al. 2007).

Using sequential extraction, the following binding forms of enzymes on fungal cell walls were identified. Fungal enzymes aimed at being secreted are synthesised at ribosomes, glycosilated in the endoplasmatic reticulum, eventually modified during transport in Golgi vesicles and finally transported to the plasmalemma where they leave the cell interior. Besides the classical way, alternatives of enzyme secretion are also reported (Latgé 2007). Irrespective of the secretion system, once transported to the outside of the cell, enzymes are either released as free enzymes or are bound in different ways at the outside. This can be at the outside the plasmalemma with GPI anchors or by binding to cell wall components after transglycosilation. Other binding forms that have been detected by 
sequential extraction of cell wall enzymes are weak ionic forces or disulfide bridges (Pitarch et al. 2002; Rast et al. 2003). Experimental evidence for the presence of relatively stable bonds of extracellular enzymes in intact ECMs is given by studies with excised ECM that after repeated washing steps in buffer maintained their activity (Pritsch et al. 2004).

\section{Methods to measure enzyme activities of field grown ECMs}

\subsection{Enzyme activity profiling of excised mycorrhizal tips}

Most of the results discussed above were obtained in pure cultures, in controlled experiments with inoculated seedlings or on a limited number of field samples. This was due to the lack of methods suitable for large scale studies of ectomycorrhizal enzymes. Only recently, the method of enzymatic activity profiling has been developed to study potential activities of extracellular enzymes as functional traits of field sampled mycorrhizae (Courty et al. 2005; Pritsch et al. 2004). This method is based on measurement of potential enzymatic activities on the surface of individual excised tips of ECMs using 96-well microplates with fluorescent or colorimetric enzyme substrates. Up to now, eight different enzyme assays have been implemented addressing the degradation of plant cell wall components (cellulose, hemicellulose, phenolic compounds, pectin), organic nitrogen (proteins/peptides, chitin), and organic phosphorus (nucleotides, phospholipids). An example of enzyme profiles of two common ectomycorrhizal types is given in Fig. 1 showing complementary functions such as phosphatase activity and specific functions such as phenoloxidase activity mainly occurring in one of the exemplified species. Considering the diversity of available substrates (Orenga et al. 2009), there is certainly a potential to extend these enzyme activity measurements to other substrates and functions of interest. This includes enzymes involved in mobilisation of nutrients not yet covered as for example organic bound sulphur which becomes a limiting nutrient in some soils due to the successful reduction of sulphate emissions from coal burning. In addition, other enzymes involved in phosphate mobilisation (phosphodiesterase, phytase), nitrogen cycling (protease), or general activity measurements such as fluorescein diacetate cleavage (Verma et al. 2008) could be adapted for microplate assays.

A last issue to mention is the possible contribution of microorganisms (bacteria) to the enzyme activity measured on field grown ECM. Addition of antibiotics to the enzyme assays had no influence on enzyme activities (Cullings et al. 2008) suggesting a minor contribution of bacteria.

6.2 Possible approaches to include mycelia in enzyme activity profiling

Enzyme activity measurements have several advantages. They are relatively fast and inexpensive allowing highthroughput functional analyses. Moreover, especially when using fluorogenic substrates, enzyme activity detection is very sensitive enabling rapid analyses on minute sample materials or weakly active samples. However, also some disadvantages and restrictions in use are connected with the method of enzyme activity profiling.

The necessity to extract ECM root tips from soil involves a cleaning step and the removal of soil particles before assaying. For contact and short distance explorationtype mycorrhizae, the activity of an excised tip may represent the activity of the whole mycorrhizal functional unit. In the case of medium and long-distance exploration types, it is inevitable that the external mycelia are almost entirely removed. Thereby, the structure considered to be most important for soil exploration and thus for nutrient exploitation is ignored. This problem has already been discussed by Courty et al. (2005), and is still not solved because of the obvious difficulties in getting access to field grown mycelia. Possible approaches separating mycelia from soil could be the use of mesh bags filled with sand and buried in the forest floor which was shown to become colonised by mycelia of saprotrophic and mycorrhizal fungi (Kjøller 2006; Wallander et al. 2001). Alternatively, flat rhizoboxes constructed from slim cases and separated from soil by a fine mesh could be used to obtain field grown roots and mycelia (Nikolova et al. 2006). Mycelia obtained by either technique can be harvested relatively easily without contaminating soil, subjected to enzyme activity measurements, and identified using standard PCR techniques. It would be an important step in addressing the question how enzyme activities of external mycelia differ from those of the mantle or from fruiting bodies (Agerer et al. 2000).

\subsection{In situ measurements of enzyme activities} using the enzyme imprint technique

Another approach to study nutrient exploitation by ECM communities through enzyme activities is enzyme imprinting of undisturbed soil profiles (Dong et al. 2007; Grierson and Comerford 2000). For this purpose, root windows have to be installed in place at forest sites to allow development of roots and mycelia. For enzyme imprinting, root windows are opened and their surface is brought in contact with nylon membranes coated with enzyme substrates. This method has the striking advantage that enzyme activities can be localised 


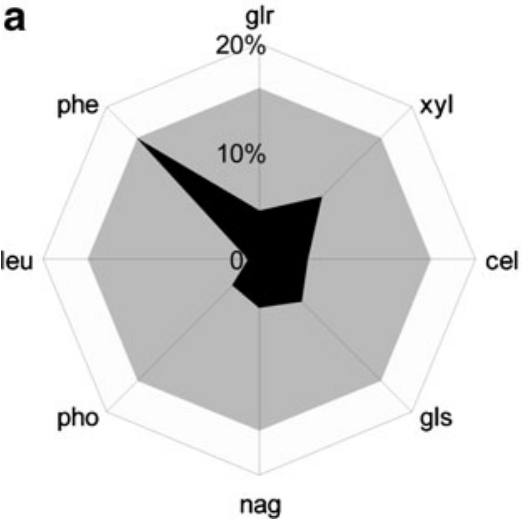

Fig. 1 Distinct enzymatic profiles of two common ECMs on Norway spruce (Picea abies (L.) Karst.) sampled within the O-horizon a Cenococcum geophilum Fr., b Russula ochroleuca (Pers.) Fr.. Sampling took place in October 2007 at the mixed beech-spruce stand "Kranzberger Forst" in Germany (for a site description see Pretzsch et al. 1998). The grey area indicates the proportion of the morphotype within the ECM community (number of tips colonised by morphotype/total number of tips) which was $59 / 372=15.8 \%$ for $C$. geophilum and $30 / 372=8.1 \%$ for $R$. ochroleuca; the black area shows the relative contribution [\%] of each morphotype to the total enzymatic activities of the community (activity $\times$ proportion of each

and assigned to specific compartments of the studied soil profile, i.e. non-mycorrhizal roots, mycorrhizae, mycelia, rhizomorphs, and bulk soil (Dong et al. 2007).

A disadvantage of this method is that root windows have to be installed well in advance before analyses can be made, thus limiting the number of samples and sites of study. However, it is a very interesting approach that may also enable targeted studies of the distribution of nutrients in relation to the distribution of enzyme activities in different compartments and fungal structures in the soil.

\section{Factors influencing the enzyme activities of ECM communities}

Increasing datasets on enzymatic profiles of ECMs reveal a high functional diversity among different members of ECM communities, with rather individual enzyme profiles. However, essential functions such as phosphatase activity seem to be redundant within the ECM community while specific functions such as phenoloxidase activity seem to be restricted to some species (Buée et al. 2007; Courty et al. 2006; Courty et al. 2005; Rineau and Garbaye 2009) and Fig. 1. In addition, several studies showed the influence of location and soil horizon on enzyme activities of a single species suggesting that the secretion of extracellular enzymes can-at least within a certain range that has to be tested for each fungal species or even genet-be adapted to the environment (Buée et al. 2007; Courty et al. 2005).

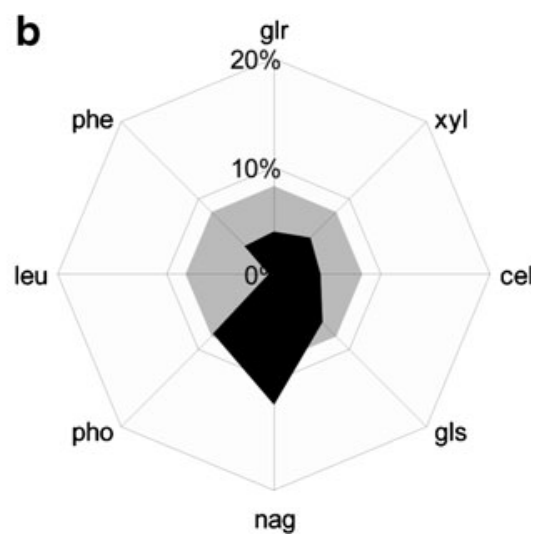

morphotype/sum of activities of all morphotypes). The contribution of C. geophilum and R. ochroleuca to the activity of the total community was lower for most enzyme activities than could be expected from their proportion in the community with few exceptions: $C$. geophilum had relatively high phenoloxidase activity, and $R$. ochroleuca showed relatively high phosphatase and $\mathrm{N}$-acetylglucosaminidase activities. Both ECMs lack leucine aminopeptidase activity. glr glucuronidase, xyl xylosidase, cel cellobiohydrolase, gls ß-glucosidase, nag $\mathrm{N}$ acetylglucosaminidase, pho acid phosphatase, leu leucine aminopeptidase, phe phenoloxidase. Data for this figure were kindly provided by Jana Ernst

During the course of a year, shifts in the availability of carbon and nutrients may not only shape the structure of the ECM community but consequently also its enzymatic activities. Carbon and nutrient availability in forest ecosystems is determined by annual cycles of temperature and depends on water supply and carbon source availability (litter fall in autumn, starch accumulation in roots during winter, remobilisation of starch and root growth in spring, and maximal photosynthesis in summer with ample supply of easily available carbon). Buée et al. (2005) and Courty et al. (2006) found changes in enzyme activities in the annual course of distinct species suggesting that different ECM types perform complementary functions depending on the season. Mosca et al. (2007) generally found strongly increased enzyme activities in ECM communities during winter compared with spring in a declining oak stand suggesting a stimulation of enzyme activities by the amount of nutrients contained in or released from recent litter.

Anthropogenic disturbances are manifold and may severely influence soil processes. Enzymatic profiles within a single species differed according to the location and the position in the soil profile suggesting that each species may adapt to local soil conditions (Courty et al. 2005). Because of its direct enzyme inhibiting properties, heavy metal contamination has been shown to decrease all tested enzyme activities in a study with artificially polluted lysimeters (Pritsch et al. 2006). More indirect effects on enzyme activities could be expected when the imposed stress factors alter carbon source availability. Elevated $\mathrm{CO}_{2}$ is increasing carbon supply and improving litter quality. In 
the contrary elevated ozone decreases the quantity and quality of carbon either translocated directly to the root or indirectly through litter fall. Other factors connected to global climate change such as untimely or prolonged periods of drought, altered precipitation and temperature patterns may affect enzyme activities related to carbon cycling in forest ecosystems.

The ubiquitous presence of prokaryotes (archaea, bacteria) and eukaryotes in the mycorrhizosphere and on the surface of ectomycorrhizae is well documented (Garbaye 1994; Bomberg and Timonen 2007; Calvaruso et al. 2007; Frey-Klett et al. 2007, Buée et al. 2009). There are increasing reports on interactions of saprotrophic fungi and bacteria with ECM in nutrient release from complex substrates (Koide and Kabir 2001; Leake et al. 2002; Nurmiaho-Lassila et al. 1997; Timonen et al. 1998; Wu et al. 2005; Wu et al. 2003). This functional assembly may vary with time, i.e. having different colonisers on younger than older parts of the mycorrhizosphere or with environmental conditions, for example a reduction of bacterial colonisation of the hyphal mantle under drought conditions (A. Hartmann, personal communication). These multitrophic associations deserve further studies addressing structural and functional dynamics as well as possible synergies within the resulting microbial communities.

Nevertheless, when studying the role of tree stands in nutrient cycling at the ecosystem level, the relevant actor is the whole ECM root tip and its emanating mycelial structures, whatever the diversity of active bacteria they contain. This is precisely what is used in the methods described here.

\section{Summary and conclusions}

There are several open research questions connected to the role of ECMs in nutrient cycling of forests that may be important when changes in ECM communities have to be interpreted with respect to ecosystem resistance and resilience towards environmental stress. Interesting topics have been raised: do plants select their fungal symbionts for specific functions (Koide et al. 2007), or from the fungal side, what determines the plasticity of ECM functions related to nutrient availability and how do they react to disturbances? The relation between nutrient and carbon source availability and functions of ectomycorrhizal and decomposer communities particularly deserve further research efforts. These multitrophic ectomycorrhizosphere associations should be explored towards their functional potential and versatility under changing environmental conditions.

Acknowledgments The authors thank the European Science foundation for supporting the exploratory workshop "Diversity and
Function in Ectomycorrhizal communities" (Nancy (F), December 2009). KP and JG received research grants from the French National Research Agency in the frame of the project "FUNDIV" (ANR-06BDIV-06). KP is grateful to the German research foundation for continuous support in the frame of SFB607 "Growth and Parasite Defence".

Open Access This article is distributed under the terms of the Creative Commons Attribution Noncommercial License which permits any noncommercial use, distribution, and reproduction in any medium, provided the original author(s) and source are credited.

\section{References}

Abuzinadah RA, Read DJ (1986) The role of proteins in the nitrogen nutrition of ectomycorrhizal plants. I. Utilization of peptides and proteins by ectomycorrhizal fungi. New Phytol 103:481-493

Abuzinadah RA, Finlay RD, Read DJ (1986) The role of proteins in the nitrogen nutrition of ectomycorrhizal plants II. Utilization of protein by mycorrhizal poants of Pinus contorta. New Phytol 103:495-506

Agerer R (2001) Exploration types of ectomycorrhizae. Mycorrhiza 11:107-114

Agerer R (2007) Fungal relationships and structural identity of their ectomycorrhizae. Mycol Prog 5:67-107

Agerer R, Schloter M, Hahn C (2000) Fungal enzymatic activity in fruitbodies. Nova Hedwig 71:315-336

Alexander IJ, Hardy K (1981) Surface phosphatase activity of Sitka spruce mycorrhizas from serpentine site. Soil Biol Biochem 13:301-305

Alvarez M, Gieseke A, Godoy R, Härtel S (2006) Surface-bound phosphatase activity in ectomycorrhizal fungi: a comparative study between a colorimetric and a microscope-based method. Biol Fertil Soils 42:561-568

Antibus RK, Sinsabaugh RL, Linkins AE (1992) Phosphatase activities and phosphorus uptake from inositol phosphate by ectomycorrhizal fungi. Can J Bot 70:794-801

Bae KS, Barton LL (1989) Alkaline phosphatase and other hydrolyases produced by Cenococcum graniforme, an ectomycorrhizal fungus. Appl Environ Microbiol 55:2511-2516

Baldrian P (2006) Fungal laccases: occurrence and properties. FEMS Microbiol Rev 30:215-242

Baldrian P (2009) Ectomycorrhizal fungi and their enzymes in soils: is there enough evidence for their role as facultative soil saprotrophs? Oecologia 161:657-660

Bartlett EM, Lewis DH (1973) Surface phosphatase activity of mycorrhizal roots. Soil Biol Biochem 5:249-257

Bending GD, Read DJ (1996) Nitrogen mobilization from proteinpolyphenol complex by ericoid and ectomycorrhizal fungi. Soil Biol Biochem 28:1603-1612

Bomberg M, Timonen S (2007) Distribution of cren- and euryarchaeota in Scots pine mycorrhizospheres and boreal forest humus. Microb Ecol 54:406-416

Bruns TD (1995) Thoughts on the processes that maintain local species diversity of ectomycorrhizal fungi. Plant Soil 170:63-73

Bruns TD, Shefferson RP (2004) Evolutionary studies of ectomycorrhizal fungi. Can J Bot 82:1122-1132

Buée M, Vairelles D, Garbaye J (2005) Year-round monitoring of diversity and potential metabolic activity of the ectomycorrhizal community in a beech (Fagus silvatica) forest subjected to two thinning regimes. Mycorrhiza 15:235-245

Buée M, Courty PE, Mignot D, Garbaye J (2007) Soil niche effect on species diversity and catabolic activities in an ectomycorrhizal fungal community. Soil Biol Biochem 39:1947-1955 
Buée M, De Boer W, Martin F, van Overbeek L, Jurkevitch E (2009) The rhizosphere zoo: an overview of plant-associated communities of microorganisms, including phages, bacteria, archaea, and fungi, and of some of their structuring factors. Plant Soil 321:189-212

Cairney JWG, Taylor AFS, Burke RM (2003) No evidence for lignin peroxidase genes in ectomycorrhizal fungi. New Phytol 160:461462

Calvaruso C, Turpault M-P, Leclerc E, Frey-Klett P (2007) Impact of ectomycorrhizosphere on the functional diversity of soil bacterial and fungal communities from a forest stand in relation to nutrient mobilization processes. Microb Ecol 54:567-577

Chen DM, Bastias BA, Taylor AFS, Cairney JWG (2003) Identification of laccase-like genes in ectomycorrhizal basidiomycetes and transcriptional regulation by nitrogen in Piloderma byssinum. New Phytol 157:547-554

Conn C, Dighton J (2000) Litter quality influences on decomposition, ectomycorrhizal community structure and mycorrhizal root surface acid phosphatase activity. Soil Biol Biochem 32:489 496

Courty P-E, Pritsch K, Schloter M, Hartmann A, Garbaye J (2005) Activity profiling of ectomycorrhiza communities in two forest soils using multiple enzymatic tests. New Phytol 167:309-319

Courty P-E, Pouysegur R, Bueé M, Garbaye J (2006) Laccase and phosphatase activities of the dominant ectomycorrhizal types in a lowland oak forest. Soil Biol Biochem 38:1219-1222

Cullings K, Courty P-E (2009) Saprotrophic capabilities as functional traits to study functional diversity and resilience of ectomycorrhizal community. Oecologia 161:661-664

Cullings K, Ishkhanova G, Henson J (2008) Defoliation effects on enzyme activities of the ectomycorrhizal fungus Suillus granulatus in a Pinus contorta (lodgepole pine) stand in Yellowstone National Park. Oecologia 158:77-83

Dong S, Brooks D, Jones MD, Grayston SJ (2007) A method for linking in situ activities of hydrolytic enzymes to associated organisms in forest soils. Soil Biol Biochem 39:2414-2419

Finlay RD, Frostegard A, Sonnerfeldt A-N (1992) Utilization of organic and inorganic nitrogen sources by ectomycorrhizal fungi in pure culture und in symbiosis with Pinus contorta Dougl. ex Loud. New Phytol 120:105-116

Frey-Klett P, Garbaye J, Tarkka M (2007) The mycorrhiza helper bacteria revisited. New Phytol 176:22-36

Garbaye J (1994) Helper bacteria: a new dimension to the mycorrhizal symbiosis. New Phytol 128:197-210

Grierson PF, Comerford NB (2000) Non-destructive measurement of acid phophaatase activity in the thizosphere using nitrocellulose membranes and image analysis. Plant Soil 218:49-57

Guidot A, Verner M-C, Debaud J-C, Marmeisse R (2005) Intraspecific variation in use of different organic nitrogen sources by the ectomycorrhizal fungus Hebeloma cylindrosporum. Mycorrhiza 15:167-177

Hibbett D, Matheny PB (2009) The relative ages of ectomycorrhizal mushrooms and their plant hosts estimated using Bayesian-relaxed molecular clock analyses. BMC Biol 7:13

Ho I (1989) Acid phosphatase, alkaline phosphatase, and nitrate reductase activity of selected ectomycorrhizal fungi. Can J Bot $67: 750-753$

Ho I, Zak B (1979) Acid phosphatase activity of six ectomycorrhizal fungi. Can J Bot 57:1203-1205

Hobbie EA, Horton TR (2007) Evidence that saprotrophic fungi mobilise carbon and mycorrhizal fungi mobilise nitrogen during litter decomposition. New Phytol 173:447-449

Hrynkiewicz K, Baum C, Leinweber P (2009) Mycorrhizal community structure, microbial biomass $\mathrm{P}$ and phosphatase activities under Salix polaris as influenced by nutrient availability. Eur J Soil Biol 45:168-175
Hutchison LJ (1990) Studies on the systematics of ectomycorrhizal fungi in axenic culture. II. The enzymatic degradation of selected carbon and nitrogen compounds. Can J Bot 68:1522-1530

Joanisse GD, Bradley RL, Preston CM, Bending GD (2009) Sequestration of soil nitrogen as tannin-protein complexes may improve the competitive ability of sheep laurel Kalmia angustifolia relative to black spruce (Picea mariana). New Phytol 181:187-198

Kalbitz K, Solinger S, Park J-H, Michalzik B, Matzner E (2000) Controls on the dynamics of dissolved organic matter in soils: a review. Soil Sci 165:277-304

Keller G (1996) Utilization of inorganic and organic nitrogen sources by high-subalpine ectomycorrhizal fungi of Pinus cembra in pure culture. Mycol Res 100:989-998

Kjøller R (2006) Disproportionate abundance between ectomycorrhizal root tips and their associated mycelia. FEMS Microbiol Ecol 58:214-224

Koide RT, Kabir Z (2001) Nutrient economy of red pine is affected by interactions between Pisolithus tinctorius and other forest-floor microbes. New Phytol 150:179-188

Koide RT, Courty P-E, Garbaye J (2007) Research perspectives on functional diversity in ectomycorrhizal fungi. New Phytol 174:240-243

Koide R, Sharda JN, Herr JR, Malcolm GM (2008) Ectomycorrhizal fungi and the biotrophy-saprotrophy continuum. New Phytol 178:230-233

Lambers H, Mougel C, Jaillard B, Hinsinger P (2009) Plant microbesoil interactions in the rhizosphere: an evolutionary perspective. Plant Soil 321:83-115

Latgé J-P (2007) The cell wall: a carbohydrate armour for the fungal cell. Mol Microbiol 66:279-290

Leake JR, Read DJ (1990) Chitin as a nitrogen source for mycorrhizal fungi. Mycol Res 94:993-1008

Leake J, Read DJ (1997) Mycorrhizal fungi in terrestrial habitats. In: Wicklow DT, Söderström B (eds) The Mycota, vol 4, Environmental and microbial relationships. Springer, Berlin, pp 281-301

Leake JR, Donnelly DP, Boddy L (2002) Interactions between ectomycorrhizal and saprotrophic fungi. In: van der Heijden MGA, Sanders IR (eds) Mycorrhizal ecology. Springer, Berlin, pp 346372

Lilleskov EA, Hobbie EA, Fahey TJ (2002) Ectomycorrhizal fungal taxa differing in response to nitrogen deposition also differ in pure culture organic nitrogen use and natural abundance of nitrogen isotopes. New Phytol 154:219-231

Lim BL, Yeung P, Cheng C, Hill JE (2007) Distribution and diversity of phytate-mineralizing bacteria. ISME J 1:321-330

Lindahl BD, Taylor AFS (2004) Occurrence of $N$-acetylhexosaminidaseencoding genes in ectomycorrhizal basidiomycetes. New Phytol 164:193-199

Luis P, Kellner H, Zimdars B, Langer U, Martin F, Buscot F (2005) Patchiness and spatial distribution of laccase genes of ectomycorrhizal, saprotrophic, and unknown basidiomycetes in the upper horizons of a mixed forest cambisol. Microb Ecol 50:570-579

Lundeberg G (1970) Utilisation of various nitrogen sources, in particular bound soil nitrogen, by mycorrhizal fungi. Stud Forestalia Suecica 79:1-95

Martin F, Laurent P, de Carvalho D, Burgess T, Murphy P, Nehls U, Tagu D (1995) Fungal gene expression during ectomycorrhiza formation. Can J Bot 73(suppl 1):S541-S547

Martin F, Laurent P, de Carvalho D, Voiblet C, Balestrini R, Bonfante P, Tagu D (1999) Cell wall proteins of the ectomycorrhizal basidiomycete Pisolithus tinctorius: identification, function, and expression in symbiosis. Fungal Genet Biol 27:161-174

McElhinney C, Mitchell DT (1993) Phosphatase activity of four ectomycorrhizal fungi in a Sitka spruce-Japanese larch plantation in Ireland. Mycol Res 97:725-732 
Mosca E, Montecchio L, Scattolin L, Garbaye J (2007) Enzymatic activities of three ectomycorrhizal types of Quercus robur L. in relation to tree decline and thinning. Soil Biol Biochem 39:28972904

Nikolova P, Blaschke H, Matyssek R (2006) Digital in situ recording of fine-root architecture and growth dynamics. Handbook of methods used in rhizosphere research. In: Finlay R (ed) Luster J. Swiss Federal Reserch Institute WSL, Birmensdorf, pp 170-171

Nurmiaho-Lassila E-L, Timonen S, Haahtela K, Sen R (1997) Bacterial colonization patterns of intact Pinus sylvestris mycorrhizospheres in dry pine forest soil: an electron mycroscopy study. Can J Microbiol 43:1017-1035

Nygren C, Rosling A (2009) Localisation of phosphomonoesterase activity in ectomycorrhizal fungi grown on different phosphorus sources. Mycorrhiza 19:197-204

Orenga S, James AL, Manafi M, Perry JD, Pincus DH (2009) Enzymatic substrates in microbiology. J Microbiol Meth 79:139-155

Pasqualini S, Panara F, Antonielli M (1992) Acid phosphatase activity in Pinus pinea-Tuber albidum ectomycorrhizal association. Can $\mathrm{J}$ Bot 70:1377-1383

Perez-Moreno J, Read DJ (2000) Mobilization and transfer of nutrients from litter to tree seedlings via the vegetative mycelium of ectomycorrhizal plants. New Phytol 145:301-309

Pitarch A, Sanchez M, Nombela C, Gil C (2002) Sequential fractionation and two-dimensional gel analysis unravels the complexity of the dimorphic fungus Candida albicans cell wall proteome. Mol Cell Proteomics 1:967-982

Plassard C, Louche J, Ali MA, Duchemin M, Legname E, CloutierHurteau B (2011) Diversity of phosphorus mobilisation and uptake in ectomycorrhizal fungie. Ann For Sci 68:

Ponge JF (1991) Succession of fungi and fauna during decomposition of needles in a small area of Scots pine litter. Plant Soil 138:99113

Ponge J-F (2003) Humus forms in terrestrial ecosystems: a framework to biodiversity. Soil Biol Biochem 35:935-945

Pretzsch H, Kahn M, Grote R (1998) The mixed spruce-beech forest stands of the Sonderforschungsbereich "Growth or parasite defence?" in the forest district Kranzberger Forst. Forstwiss Centralblatt 117:241-257

Pritsch K, Raidl S, Marksteiner E, Blaschke H, Agerer R, Schloter M, Hartmann A (2004) A rapid and highly sensitive method for measuring enzyme activities in single mycorrhizal tips using 4methylumbelliferone labelled fluorogenic substrates in a microplate system. J Microbiol Meth 58:233-241

Pritsch K, Günthardt-Goerg MS, Munch JC, Schloter M (2006) Influence of heavy metals and acid rain on enzymatic activities in the mycorrhizosphere of model forest ecosystems. Water Snow Landscape Res 80:289-304
Rangel-Castro JI, Danell E, Taylor AFS (2002) Use of different nitrogen sources by the edible ectomycorrhizal mushroom Cantharellus cibarius. Mycorrhiza 12:131-137

Rast DM, Baumgartner D, Mayer C, Hollenstein GO (2003) Cell wallassociated enzymes in fungi. Phytochemistry 64:339-366

Read DJ, Perez-Moreno J (2003) Mycorrhizas and nutrient cycling in ecosystems - a journey towards relevance? New Phytol 157:475492

Rineau F, Garbaye J (2009) Does forest liming impact the enzymatic profiles of ectomycorrhizal communities through specialized fungal symbionts? Mycorrhiza 19:493-500

Rosling A (2009) Trees, mycorrhiza and minerals - field relevance of in vitro experiments. Geomicrobiol J 26:389-401

Smith SE, Read DJ (2008) Mycorrhizal symbiosis. Academic, Amsterdam, Boston

Taylor AFS, Fransson PM, Högberg P, Högberg MN, Plamboeck AH (2003) Species level patterns in ${ }^{13} \mathrm{C}$ and ${ }^{15} \mathrm{~N}$ abundance of ectomycorrhizal and saprotrophic fungal sporocarps. New Phytol 159:757-774

Tibbett M, Sanders FE, Cairney JWG (1998) The effect of temperature and inorganic phosphorus supply on growth and acid phosphatase production in arctic and temperate strains of ectomycorrhizal Hebeloma spp. in axenic culture. Mycol Res 102:129-135

Timonen S, Joergensen KS, Haahtela K, Sen R (1998) Bacterial community structure at defined locations of Pinus sylvestrisPaxillus involutus mycorrhizospheres in dry pine forest humus and nursery peat. Can J Microbiol 44:499-513

Treseder KK, Torn MS, Masiello CA (2006) An ecosystem-scale radiocarbon tracer to test use of litter carbon by ectomycorrhizal fungi. Soil Biol Biochem 38:1077-1082

van Aarle I, Viennois G, Amenc L, Tatry M-V, Luu D, Plassard C (2007) Fluorescent in situ RT-PCR to visualise the expression of a phosphate transporter gene from an ectomycorrhizal fungus. Mycorrhiza 17:487-494

Verma P, Dyckmans J, Militz H, Mai C (2008) Determination of fungal activity in modified wood by means of micro-calorimetry and determination of total esterase activity. Appl Microbiol Biotechnol 80:125-133

Wallander H, Nilsson LO, Hagerberg D, Baath E (2001) Estimation of the biomass and seasonal growth of external mycelium of ectomycorrhizal fungi in the field. New Phytol 151:753-760

Wu T, Sharda JN, Koide RT (2003) Exploring interactions between saprotrophic microbes and ectomycorrhizal fungi using a proteintannin complex as an $\mathrm{N}$ source by red pine (Pinus resinosa). New Phytol 159:131-139

Wu T, Kabir Z, Koide RT (2005) A possible role for saprotrophic microfungi in the $\mathrm{N}$ nutrition of ectomycorrhizal Pinus resinosa. Soil Biol Biochem 37:965-975 